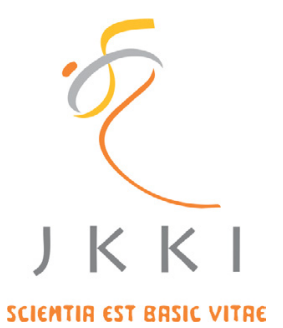

Jurnal Kedokteran dan Kesehatan Indonesia

Indonesian Journal of Medicine and Health

Journal homepage : www.journal.uii.ac.id/index.php/JKKI

\title{
Association between heel-height and low back pain in sales promotion girls
}

Andhika Rezky Bahrizal ${ }^{1}$, Meiyanti*2

${ }^{1}$ Student of Study Program of Doctor Profession, Faculty of Medicine, Trisakti University, West Jakarta, Indonesia ${ }^{2}$ Departement of Pharmacology and Pharmacy, Faculty of Medicine, Trisakti University, West Jakarta, Indonesia

\begin{tabular}{|c|c|}
\hline & ABSTRACT \\
\hline ARTICLE INFO & $\begin{array}{l}\text { Background: The Prevalence of LBP in Indonesia continues to increase, } \\
\text { while the exact cause cannot be identified. The facts show that most of }\end{array}$ \\
\hline $\begin{array}{l}\text { Keywords: } \\
\text { Low back pain, } \\
\text { disability, } \\
\text { heel heights, } \\
\text { sales promotion girls, } \\
\text { long wearing high heels }\end{array}$ & $\begin{array}{l}\text { LBP is caused by occupational health problems rather than organic } \\
\text { diseases, which one of them is the habit of wearing high-heeled shoes. } \\
\text { Besides having an aesthetic function, high-heeled shoes also give negative } \\
\text { effects on health. } \\
\text { Obiective: To evaluate the association between the usage and duration of }\end{array}$ \\
\hline $\begin{array}{l}\text { *Corresponding author: } \\
\text { meiyanti_suhardi@yahoo.com } \\
\end{array}$ & $\begin{array}{l}\text { high heels with LBP, as well as evaluating disability due to LBP in female } \\
\text { salesperson }\end{array}$ \\
\hline DOI : 10.20885/JKKI.Vol8.Iss3.art9 & Methods: The study used analytic observational study with cross-sectional \\
\hline $\begin{array}{l}\text { History: } \\
\text { Received: November 14, } 2017 \\
\text { Accepted: December 15, } 2017 \\
\text { Online: December 18, } 2017\end{array}$ & $\begin{array}{l}\text { design that includes } 123 \text { sales promotion girls in one of department } \\
\text { stores, Cengkareng, West Jakarta which was carried out from November } \\
\text { to December } 2015 \text {. The data was collected through the interview which } \\
\text { includes characteristics of the subjects, complaint history of low back } \\
\text { pain (LBP), measurement of heel heights, and anthropometry data. The } \\
\text { intensity of pain is assessed by Visual Analogue Scale, whilst the degree } \\
\text { of disability is assessed by using Oswestry Low Back Pain Disability } \\
\text { Questionnaire. Data analysis is performed by using Fisher's test with a } \\
\text { significance level p<0.05 software SPSS for Windows version } 21 \text {. } \\
\text { Results : The majority of } 20 \text { to } 25 \text {-year-old sales promotion girls with a } \\
\text { normal nutritional status wear } 5-7 \text { cm-high-heeled shoes for more than } \\
\text { one year. About } 68 \% \text { of them complain of low back pain (LBP), where } 11 \% \\
\text { of subjects were obtained with suspected disability due to LBP complaint. } \\
\text { The heel heights is not correlated with LPB complaints, but the working } \\
\text { period of sales promotion girls is (p=0.000). } \\
\text { Conclusion: There is no correlation between high heel shoes with low } \\
\text { back pain. There is a relationship between the working period with low } \\
\text { back pain. }\end{array}$ \\
\hline
\end{tabular}

Latar Belakang: Prevalensi low back pain di Indonesia terus meningkat, dimana tidak ditemukan penyebab spesifik yang dapat diidentifikasi. Fakta menunjukkan bahwa sebagian besar low back pain disebabkan oleh masalah okupasional dibanding penyakit organik. Salah satunya adalah penggunaan sepatu hak tinggi. Selain memiliki fungsi estetik, sepatu hak tinggi juga memiliki dampak negatif bagi kesehatan.

Tujuan: Mengevaluasi hubungan antara penggunaan dan durasi sepatu hak tinggi dengan LBP, serta mengevaluasi kecacatan akibat LBP pada pramuniaga perempuan.

Metode: Desain studi penelitian secara observasional analitik dengan pendekatan potong lintang yang diikuti oleh 123 pramuniaga perempuan di salah satu plaza di daerah Cengkareng Jakarta Barat, 
selama bulan November hingga Desember 2015. Pengumpulan data dengan melakukan wawancara yang meliputi karakteristik subjek, riwayat keluhan low back pain, pengukuran tinggi hak sepatu, dan data antropometri. Pengukuran keluhan LBP menggunakan Visual Analog Scale, sedangkan derajat disabilitas menggunakan Oswestry Low Back Pain Disability Questionnaire. Analisis data menggunakan uji Fisher dengan tingkat kemaknaan $p<0,05$ software SPSS for Windows versi 21.

Hasil : Mayoritas pramuniaga berusia antara 20-25 years dengan status gizi normal dan menggunakan tinggi hak sepatu 5-7 cm lebih dari 1 years. Sebesar 68\% mengeluhkan low back pain, dimana 11\% dari subjek didapatkan suspek disabilitas akibat keluhan low back pain. Tinggi hak sepatu tidak berhubungan dengan keluhan LBP, akan tetapi masa kerja pramuniaga berhubungan dengan adanya keluhan low back pain ( $p=0,000)$.

Kesimpulan : Tidak terdapat hubungan antara tinggi hak sepatu dengan keluhan low back pain. Ada hubungan antara masa kerja dengan keluhan low back pain .

\section{INTRODUCTION}

Low back pain (LBP) is not a name of a disease, instead it is a symptom characterized by pain in an anatomical area with various length of occurence and pathological mechanism. ${ }^{1}$ In Indonesia, the prevalence of LBP is estimated between $7,6 \%$ to $37 \% .^{2}$ Approximately, in $85 \%$ of LBP population, has no specified underlying diseases. ${ }^{3}$ Facts show that most LBP cases are caused by occupational hazzard rather than organic diseases. ${ }^{1}$ The peak age group for back pain is between $25-60$ years old. ${ }^{4}$

Apart from having a health function, shoes also have an esthetical function. ${ }^{5}$ Some corporation, especially in department store, female salesperson is obligated to wear high heeled shoes. This can cause health problem because they work in a standing position for a long period of time with high mobility.

Previous research had shown that the usage of high heels can increase the occurence of lumbar lordosis which correlate to LBP.6,7 Without intervention, LBP can be worsen and can cause disability. ${ }^{8,9}$ However, there was also another study that showed the usage of high heels could decrease the occurence of lumbar lordosisi lain pihak, ada pula penelitian yang mengatakan terdapat penurunan lordosis lumbar ketika. ${ }^{10}$

Due to the disparity of finding, we would like to confirm these previous research about the association between high heeled shoes and LBP in female sales person, also considering that the literatures regarding to this matter is still limited in Indonesia.

The general objective of this study is to decrease the morbidity of LBP as well as prevent its occurence in female salesperson. The specific objective is to evaluate the association between the usage and duration of high heels with LBP, as well as evaluating disability due to LBP in female salesperson.

\section{METHODS}

This study used an observational analytic with cross sectional approach. The criteria of inclusion include female salesperson, age between 20 40 years old, working routine mostly standing or walking in $\geq 3$ hours/worktime, use high heeled shoes $\geq 5 \mathrm{~cm}$ in pumps or stilettos, normal BMI (18.5-22.9 kg/m2) or overweight (23-24.9 $\mathrm{kg} / \mathrm{m} 2$ ), and working period minimal 8 hours/ day. The exclusion criteria include pregnancy or post-partum, history of anatomical disorder, history of musculosceletal injury (fracture, spinal disorder, cervical disc injury, hiperlordosis, hiperkiphosys, and scoliosis), currently suffering from musculosceletal diseases (for instance : rheumatoid arthritis (RA) and osteoarthritis $(\mathrm{OA})$, deformity of lower extremity, and abnormal gait). Research subjects were 123 people, choosen by consecutive sampling.

Subjects who fulfilled inclusion criteria and did not have any exclusion criteria were asked for willingness to join the research by informed consent. Data collection was done using interviews and questionairre which included subject characteristic, history of low back pain (LBP), measurement of heel height, and antropometry. The measurement of pain symptom of LBP was done using Visual Analog Scale, while the degree of disability was measured by Oswestry Low Back Pain Disability Questionnaire. Instruments used in 
this study were digital scale, microtoise, and tape measure. ${ }^{11,12}$

Collected data were processed through several steps, including data editing, coding, entry, and cleaning using SPSS version 21 for Windows 8.1. Data analysis was done with Chi-Square and Fisher alternative test with significancy $\mathrm{p}<0,05$.

\section{RESULTS}

The respondents in this study were 123 research subjects, who were between the age of 20-40 years old, dominated by people between 20-25 years old for as much as $65 \%$ or 80 people. There were $78,9 \%$ or 97 respondents with normal BMI, and $21,1 \%$ or 26 respondents with overweight BMI.

Table 1. Characteristic distribution, heel-height, work duration, LBP symptoms

\begin{tabular}{ccc}
\hline $\begin{array}{c}\text { Characteristic } \\
\text { (n=123) }\end{array}$ & $\begin{array}{c}\text { Total } \\
\text { (n) }\end{array}$ & $\begin{array}{c}\text { Precentage } \\
\text { (\%) }\end{array}$ \\
\hline Age & & \\
$20-25$ years & 80 & 65,0 \\
$26-30$ years & 18 & 14,6 \\
$31-35$ years & 11 & 8,9 \\
36 - 40 years & 14 & 11,4 \\
BMI & & \\
Normal & 97 & 78,9 \\
Overweight & 26 & 21,1 \\
Heel-height & & \\
5 - 7 cm & 110 & 89,4 \\
$8-10$ cm & 13 & 10,6 \\
Work duration & & \\
< 1 years & 28 & 22,8 \\
$\geq 1$ years & 95 & 77,2 \\
LBP symptoms & & 68,3 \\
Exist & 84 & 31,7 \\
Not exist & 39 & \\
\hline
\end{tabular}

The distribution of heel-height, working period, and LBP symptoms showed that most respondents used 5-7 cm heels (mid heel), which is 110 people or $89,4 \%$. There were $77,2 \%$ or
92 respondents had work period for over 1 year. While, there were 84 respondents or $68,3 \%$ had symptoms of LBP (Table 1). Based on the symptoms of LBP, an assessment for disability was done, there were $73(86,9 \%)$ respondents who did not suffer from disability and 11 ( $13.11 \%$ ) subjects were suspected to suffer from disability.

Table 2. Association between heel-height with LBP

\begin{tabular}{|c|c|c|c|c|c|}
\hline \multirow{3}{*}{ Heel-height } & \multicolumn{4}{|c|}{ Symptoms of LBP } & \multirow{3}{*}{$P$ value } \\
\hline & \multicolumn{2}{|c|}{ Yes } & \multicolumn{2}{|c|}{ No } & \\
\hline & $\mathbf{n}$ & $\%$ & $\mathbf{N}$ & $\%$ & \\
\hline $\begin{array}{l}5-7 \mathrm{~cm} \\
\text { (mid heel) }\end{array}$ & 73 & 66,4 & 37 & 33,6 & \\
\hline $\begin{array}{l}8-10 \mathrm{~cm} \\
\text { (high heel) }\end{array}$ & 11 & 84,6 & 2 & 15,4 & $0, \angle 23 \|$ \\
\hline Total & 84 & 68,3 & 39 & 31,7 & \\
\hline
\end{tabular}

There were $66,4 \%$ of respondents who wore high-heels with heel-height between $5-7 \mathrm{~cm}$ and also suffered from LBP. While there were $84,6 \%$ of respondents who wore high-heels with heelheight between 8-10 cm and also suffered from LBP. Based on Fisher test, $p$ value was found 0,223 ( $p>0,05$ ), thus it can be concluded that there is no statistically significant association between heel-height and LBP symptoms in female salesperson (Table 2).

Table 3. The association between work duration and LBP symptom

\begin{tabular}{lccccc}
\hline \multicolumn{1}{c}{$\begin{array}{c}\text { Work } \\
\text { Duration }\end{array}$} & \multicolumn{2}{c}{ Yes } & \multicolumn{2}{c}{ No } & P value \\
& n & \% & N & $\%$ & \\
\hline $\begin{array}{l}\text { 1 year } \\
\text { (short) }\end{array}$ & 1 & 3,6 & 27 & 96,4 & \\
$\geq 1$ year & 83 & 87,4 & 12 & 12,6 & $0,000 \neq$ \\
$\begin{array}{l}\text { (long) } \\
\text { Total }\end{array}$ & 84 & 68,3 & 39 & 31,7 & \\
\hline ₹: Chi-Square & & & & &
\end{tabular}

Based on Table 3, there were $3,6 \%$ of respondents with work duration less than 1 year who had symptoms of LBP. While there 
were $87,4 \%$ of respondents with work duration more than 1 year who had symptoms of LBP. Chi-Square test showed $p$ value $0,000(p<0,05)$, thus it can be concluded that there is statistically significant association between work duration and LBP in female salesperson. Respondents who had worked for $\geq 1$ year were more prone to have LBP symptoms compare to those who had only worked for less than 1 year.

\section{DISCUSSION}

There were $89,4 \%$ of female salesperson who used high heels with heel-height between 5-7 cm, in which the average wore $5 \mathrm{~cm}$ heelheight. The rest, used high heels with heelheight between 8-10 cm. Many department store obliged their female salesperson to wear at least $5 \mathrm{~cm}$ high heels. Based on a research by Chuanphis Boonkerd, there would be an increase of GRF while walking in 7,62 cm high heels. ${ }^{13}$ Another research by Koussihouede Fifame Eudia Nadege, et al, Dalton E, and Ann Mika, et al showed that the usage of high heels with heel-height more than $5 \mathrm{~cm}$ could cause changes in body load distribution and increase the activity of paraspinal muscle which correlate with musculosceletal diseases, one of which is LBP. ${ }^{14-16}$ Standing for more than four hours can induced muscle tension in back region and cause discomfort and pain in lower back. A survey conducted on 200 female between the age of 20-35 years old who had been wearing high heels regularly for more than 1 year, showed that $58 \%$ complained lumbar pain and $55 \%$ starting to feel uncomfortable when wearing high heels with heel-height between 6-9 $\mathrm{cm}^{7}$

The respondents in this study were between the age of 20 to 40 years old. The average age of respondents were 24 years old, in which the youngest was 20 years old and the oldest was 40 years old. Most high heels users were between the age of 20 to 25 years old, as much as $65 \%$. This age is a productive age. This result is similar with previous research by Pannell SL, where the precentage of female who wear high-heels were found highest between the age group of $18-24$ years, as much as $49 \%{ }^{8} \mathrm{~A}$ research by
Steven, Jl showed that low back pain in workers usually start to occur in young adults, in which the peak prevalence is between the age of 25 60 years old. ${ }^{4}$

As much as 77,2\% salesperson had long work duration, which is more than 1 year, in which the average had worked for 4 years. A previous research by Muhajirin Isnain mentioned that the average work duration in his research was 5 years. ${ }^{17}$ Furtado, et al. found that the work duration of $\geq 1$ years in addition to 4 hours or more per day duration of use can induce LBP symptoms. ${ }^{18}$ As much as $68,3 \%$ or 84 respondents complained LBP, while the rest did not. This result is similar with a previous research by Muhajirin Isnain, in which there was $67,9 \%$ respondents who complained LBP. ${ }^{17}$

LBP occurs as a compensation mechanism to balance body position while using high heels. As a result, there would be muscle tension and fatigue. If no intervention is done, LBP could worsen and cause disability. ${ }^{8,9}$ Within the 84 respondents who complained LBP, there was only 11 subjects or $13,1 \%$ who was suspected with disability based on ODI. This results was in contrast with a previous study by Yuliana, which stated that untreated LBP would develop into chronic LBP and cause disability. ${ }^{19}$

We found that there is no statistically significant association between the height of high heels with LBP in female salesperson. This is concluded from Fisher test, in which the $p$ value $=0,223(p \geq 0,05)$. Another study by de Oliveira Pezzan PA, et al. concluded that the usage of high heels had no correlation with lumbar lordosis asscociated with LBP. In contrary, he found that the usage of high heels could decrease the occurence of lumbar lordosis. ${ }^{10}$ However, this research did not directly asscociate the heigh of high-heels with LBP.

A different result was obtained by Muhajirin Isnain who concluded that there was an asscociation between high heels height with low back pain. ${ }^{17}$ However, the research by Muhajirin only included high heels with $5-7 \mathrm{~cm}$ heelheight and did not explicitly state the height of heels at risk. While in our study, we also included 
the heel-height of $8-10 \mathrm{~cm}$, thus the data is more variative. Another research by Dongwook Han and Cezar Augusto, et al also showed that high heels correlate with LBP because it could increase the activity of paraspinal muscle, eventhough it decrease lumbar lordosis. ${ }^{6,20-22}$

As is known, the etiology of LBP is multifactorial, be it anatomical position or pathological process. Anatomically, the most often etiology of LBP include any disease or injury of the muscle, faschia, ligament, bone, joint, disc, and spinal nerve. Generally, there are three main factors that affect the occurence of LBP due to the usage of high heels, include : biomechanical , occupational, and sosiodemographic factor. Biomechanical factor include posture changes, GRF activity, and anatomical changes as well as diseases. ${ }^{13}$ Occupational includes the period and duration of work, as well as the type and height of high-heel, while the sosiodemographic factor includes age, BMI, and physical activity. ${ }^{16}$

All these factors are related to each other, but not interdependent. This means that not necessarily all these factors need to exist to cause LBP to the users of high heels. The combination of these factors can increase the risk of LBP. In this research, we only observed the correlation between two occupational factors, which were the heigh of high heels and working duration with LBP in female salesperson.

Based on recent theories from literatures and research, the height of high heels would cause LBP because it induces changes in body load distribution. Approximately $90 \%$ of body weight would be concentrated in the forefoot. ${ }^{14,23}$ High heels would push the center of body load to the front excessively, so that the pelvis and spine would be out of its normal alignment, thus causing an increase of bioelectrical activity of the spine muscle and increase oxygen consumption. ${ }^{24}$ These mechanism would cause muscle stress, that gradually would cause posture changes and LBP. ${ }^{15}$

Vertical GRF increases significantly in heelheight of 7,62 cm. GRF exerted towards the body through the lower extremity would be forwarded upwards over the line of body weight and would ultimately put a strain on the spine and increase the activity of paraspinal muscle, especially spine erector muscle, thus causing LBP. ${ }^{25}$

Based on the reasons described above, it was hypothetized that the height of high heeled shoes can lead to LBP in female salesperson, however we did not found statistically significant association in this study. In relation to the absence of correlation between the height of high-heeled shoes with LBP in this research, we suspect that the assessment of various other factors is needed.

We found that there is statistically significant association between work duration while wearing high heels with the occurence of LBP in female salesperson. This was concluded from ChiSquare test where $p$ value $=0,000(p<0,05)$. The proportion difference of LBP symptoms between the work duration of $<1$ year and $\geq 1$ year is $80 \%$, equal to the minimal significancy proportion. Therefore, clinically there is association between work duration with LBP.

This result is similar with Lee CM, et al., Furtado, et al. which stated that the usage of high heels regularly every day for more than 1 year with more than four hours duration of use per day, would cause LBP and foot discomfort. In a previous research by Koesyanto $\mathrm{H}$, it was found that there was correlation between work duration with subjective symptoms of back pain. ${ }^{2}$ The exposure of excessive pressure in spine erector muscle for a long period of time, as well as posture changes that cause an increase of lumbar lordosis will induce LBP. 2,7,18

The limitation of this research is the small population and sample size. Research samples were only obtained from one location. This causes the results to not be able to be generelize because the research was done on a smale scale, so it still needs improvement and further research. In addition, the limited number of respondents caused the characteristics of the respondents to be less varied. Confounding factors of LBP, such as age, BMI, physical activity, occupational position, and musculosceletal siseases, were not fully observed. 


\section{CONCLUSSION}

The conclussion of this research is that there is no statistically significant association between the height of high heels with LBP in female salesperson. However, there is statistically significant asscociation between work duration and LBP symptoms in female salesperson. And no significant disability was found in female salesperson who complained LBP.

\section{REFERENCES}

1. Ehrlich GE. Low back pain. Bulletin of the World Health Organization. 2003;81(9):671-6.

2. Koesyanto H. Masa kerja dan sikap kerja duduk terhadap nyeri punggung. KEMAS: Jurnal Kesehatan Masyarakat. 2013;9(1):9-14.

3. Arya RK. Low back pain - Signs, symptoms, and management. Journal Indian Academy of Clinical Medicine. 2014;15(1):30-41.

4. Linton SJ. Do psychological factors increase the risk for back pain in the general population in both a cross-sectional and prospective analysis? European Journal of Pain. 2005;9(4):355-355.

5. Maha BAKS, Ticoalu SHR, Wongkar D. Pengaruh penggunaan sepatu hak tinggi terhadap risiko timbulnya varises pada tungkai bawah. Jurnal e-Biomedik. 2013;1(3):1114-9.

6. Casarin CAS, Bocalini DS, Marchetti PH, deAndrade EL, Leite GS, Serra AJ, et al. Relation between wearing high-heeled shoes and gastrocnemius and erector spine muscle action and lumbar lordosis_2014. Medical Science and Tecnology. 2014;55:16-71.

7. Lee C-M, Jeong E-H, Freivalds A. Biomechanical effects of wearing high-heeled shoes. International Journal of Industrial Ergonomics. 2001;28(6):321-6.

8. Pannell SL. The postural and biomechanical effects of high heel shoes: A literature review. Logan University; 2012.

9. Dijken C, Fjellman-Wiklund A, Hildingsson C. Low back pain, lifestyle factors and physical activity: A population basedstudy. Journal of Rehabilitation Medicine.
2008;40(10):864-9.

10. de Oliveira Pezzan PA, João SMA, Ribeiro AP, Manfio EF. Postural assessment of lumbar lordosis and pelvic alignment angles in adolescent users and nonusers of high-heeled shoes. Journal of Manipulative and Physiological Therapeutics. 2011;34(9):614-21.

11. Wong-Baker FACES Foundation. Wong-Baker FACES $\AA$ Pain Rating Scale. [Internet]. 2015 [cited 2015 Dec 11]. Available from: http://www.wongbakerfaces.org

12. Fairbank JCT, Pynsent PB. The Oswestry Disability Index. Spine. 2000;25(22):294053; discussion 52.

13. Boonkerd C. Effects of differencing heel heights on the lower limb biomechanics and energy profiles in young thai females during constant speed walking. Bangkok, Thailand: Mahidol University; 2005.

14. Dalton E. High heels and back pain [Internet]. 2010 [cited 2015 Jul 8]. Available from: http://www.erikdalton.com/media/ newsletters-online/high-heels-and-backpain

15. Mika A, Oleksy L, Mikolajczyk E, Marchewka A, Mika P. Changes of bioelectrical activity in cervical paraspinal muscle during gait in low and high heel shoes. Acta Bioeng Biomech. 2011;13(1):27-33.

16. Nadege KFE, Marie Fj, Mansourou LM, Polycarpe G, Gabriel AY, Sophia L. Wearing high heel shoes during gait: Kinematics impact and determination of comfort height. American Journal of Science. 2015;3(2):56-61.

17. Isnain M. Hubungan antara tinggi hak sepatu dan Indeks Massa Tubuh (BMI) dengan keluhan nyeri pinggang bawah pada Sales Promotion Girl (SPG) Ramayana Salatiga. Jurnal Kesehatan Masyarakat. 2013;2(1).

18. Furtado RNV, Ribeiro LH, Abdo BA, Descio FJ, Junior CEM, Serruya DC. Nonspecific low back pain in young adults: Associated risk factors. Revista Brasileira de Reumatologia. 2014;54(5):371-7.

19. Yuliana. Low back pain. CDK. 2011;38(4):270-3.

20. Russel BS. The effect of high-heeled shoes 
on lumbar lordosis: a narrative review and discussion of the disconnect between internet content and peer-reviewed literature. Journal of Chiropractic Medicine. 2010;9(4):166-73.

21. Russel BS, Muhlenkamp KA, Hoiriis KT, DeSimone CM. Measurement of lumbar lordosis in static standing posture with and without high-heeled shoes. Journal of Chiropractic Medicine. 2012;11:145-53.

22. Han D. Muscle activation of paraspinal muscles in different types of high heels during standing. Journal of Physical Therapy Science. 2015;27(1):67-9.

23. Patel C, Ariani K, Jager B, Lammers C, Myers $\mathrm{H}$, Talbott J, et al. How high heels affect your body. 2015.

24. do Nascimento NIC, Saraiva TS, Cruz Jr ATV, da Silva Souza G, Callegari B. Barefoot and high-heeled gait: changes in muscles activation patterns. Health. 2014;6:2190-6.

25. Henderson PD, Piazza SJ. A biomechanical evaluation of standing in high-heeled shoes. Journal of Biomechanics. 2004;11:25-38.

26. Koesyanto H. Masa kerja dan sikap kerja duduk terhadap nyeri punggung. KEMAS: Jurnal Kesehatan Masyarakat. 2013;9(1):9-14. 